Original Research Paper

\title{
Prevalence of Listeria monocytogenes in Raw Cow's Milk in the Region of Batna, Algeria
}

\author{
${ }^{1}$ Sabrina Rabehi, ${ }^{1}$ Bakir Mamache, ${ }^{2}$ Taha MossadakHamdi, \\ ${ }^{3}$ Asma Meghezzi and ${ }^{3}$ Khaoula Boushaba \\ ${ }^{1}$ Department of Veterinary Science, Institute of Veterinary and Agronomic Sciences, \\ University of Batna 1, Batna. Algeria \\ ${ }^{2}$ Research Laboratory HASAQ, High National Veterinary School, Algiers. Algeria \\ ${ }^{3}$ Laboratory of Molecular Biology and Microbiology of Constantine Biotechnology Research Center, \\ Constantine. Algeria
}

Article history

Received: 03-08-2021

Revised: 03-09-2021

Accepted: 13-09-2021

Corresponding Author:

Bakir Mamache

Department of Veterinary

Science, Institute of Veterinary

and Agronomic Sciences,

University of Batna 1, Batna.

Algeria

Email: mamachebakir@yahoo.fr

\begin{abstract}
The aim of this study is the detection of the presence of $L$. monocytogenes in raw milk in the region of Batna using the real-time polymerase chain reaction (real-time PCR) technique, in order to assess the riskrun by the consumer of raw milk in the study area. 65 milk samples were investigated for the detection of L. monocytogenes. The detection of the hlyA gene in all samples was done by real-time PCR assay by comparative cycle threshold method. The results obtained were negative for all the samples analyzed, therefore the prevalence of $L$. monocytogenes in the 65 samples collected in this study is $0 \%$. The absence of $L$. monocytogenes in the samples could be linked to the good health of the selected cattle. In fact, $L$. monocytogenes is considered to be very widespread in industrialized countries and rare in North Africa and Algeria.
\end{abstract}

Keywords: Listeria monocytogenes, Real-Time PCR, Raw Milk, Public Health

\section{Introduction}

L. monocytogenes is a foodborne pathogen responsible for listeriosis in humans due to its presence in raw and ready-to-eat foods which are stored at refrigeration temperature (Shi et al., 2015). L. monocytogenes is the only species of the genus Listeria to be considered as pathogen in humans (Snapir et al., 2006).It has been implicated in the original infection of environmental samples such as soil, water, manure and vegetation (Strawn et al., 2013).

The main routes of contamination for animals (especially livestock) are silage (Welchman et al., 1997) and the animals themselves. This animal carriage of $L$. monocytogenes in the agricultural environment can lead to contamination of animal products such as raw milk (Huntet al., 2012) or meat (Dmowska et al., 2013). Contamination of agricultural raw materials is a pathway for the pathogen to enter the food industry.

Contaminated food with Listeria monocytogenes is the predominant route of transmission of listeriosis to humans, a severe illness with a high mortality rate (Magalhães et al., 2017). Milk constitutes one of the main vectors of Listeria transmission; more particularly raw milk from cows due to its wide consumption.
Contaminated raw milk used in cheese-making, particularly those with soft cheeses, flowery rinds or washed rinds, promotes the multiplication of Listeria during ripening. L. monocytogenes can be isolated from soft or semi-soft, blue-veined, pressed or fresh cheese (Millet et al., 2006).

Listeria is killed, like all other bacteria by pasteurization. However, contamination can then occur at any time, by the environment or by contact with another contaminated food: You should know that Listeria multiplies between 4 and $45^{\circ} \mathrm{C}$ and is able to survive freezing temperatures (Kaismoune, 2009).

Several methods for detecting L. monocytogenes have been highlighted, but conventional culture remains a reference method according to international standards. However, the culture takes a long time between 3 and 5 days, for this, easy and fast alternative methods have been improved in order to better meet the needs by reducing the detection time. Among these methods, the PCR technique is widely used.

The vast majority of PCR tests used to identify $L$. monocytogenes use the primers of the hly $A$ gene sequence which codes for Listeroloysin O (LLO). Hly A is part of the virulence genes of Listeria (Liuet al., 2004). LLO was the first virulence factor identified in L. monocytogenes 
(Gaillard et al., 1986). The application of real-time PCR has also been developed as a specific quantitative detection method for L. monocytogenes (Hough et al., 2002)and has shown good potential for routine analysis. For real-time PCR, the specificity and the sensitivity are better, the duration of the analysis is shorter and it is the desired germ or the group of bacteria to be characterized which controls the system used (Chentouf, 2015)

In Algeria, there are few studies on the frequency of isolation of L. monocytogenes from raw milk intended for direct consumption or for the dairy industry. The aim of this study is to determine the prevalence of L. monocytogenes in raw milk collected in the region of Batna. The method used in this study is the technique of real-time PCR.

\section{Materials and Methods}

\section{Samples of Milk}

A total of 65 milk samples were taken from cows (ages 3-8 years) belonging to 3 dairy farms in the Wilaya of Batna (North-Eastern Algeria). The milk samples were collected aseptically from teats of the udder which had previously been cleaned with water and soap and then, the surface was sterilized with $70 \%$ ethanol. For each animal, the first jet of milk was removed and then $15 \mathrm{~mL}$ of milk were collected from 4 quarters in sterile Falcon tubes previously identified. The samples were immediately transported to the laboratory at $+4^{\circ} \mathrm{C}$ for DNA extraction.

This study was conducted at the Laboratory of Microbiology and Molecular Biology of Constantine Biotechnology Research Center, Algeria.

\section{Pre-Treatment of Milk}

Initially, the milk had undergone a pre-treatment as follows: A test sample of $800 \mu \mathrm{L}$ of the milk was centrifuged for $5 \mathrm{~min}$ at $10000 \mathrm{~g}$, then the supernatant was removed and the pellet was resuspended in $300 \mu \mathrm{L}$ of Phosphate-Buffered Saline (PBS).

\section{Extraction of DNA}

Genomic DNA was extracted from raw milk using a BioExtract ${ }^{\circledR}$ Column purification kit according to the manufacturer's protocol (Cat $\left.\mathrm{N}^{\circ} \mathrm{BEC} 050\right)$.

The extracted DNA is then quantified using Nanodrop® ND 8000.

The DNA was then stored at $4^{\circ} \mathrm{C}$ until use.

\section{Real-Time PCR Amplification}

Real-time PCR was used to detect the presence of $L$. monocytogenes DNA in milk samples as described in the kit BactoReal® kit Listeria monocytogenes (REF: DVEB00813). This test has been developed and validated for ABI PRISM® 7500 (Fast) instrument (Applied
Biosystems). This test allows rapid and sensitive detection of DNA of L. monocytogenes from purified milk samples.

BactoReal $^{\circledR}$ Kit Listeria monocytogenes detects the gene hlyA of L. monocytogenes.

A Positive Internal Control of the system for the detection at $\mathrm{Cy} 5(667 \mathrm{~nm})$ makes it possible to demonstrate the inhibitions of the PCR, resulting in falsenegative results when interpreting the results due to the inhibition of PCR in real time.

\section{The Reaction Mixture}

The real-time PCR assay was performed by an ABI PRISM $^{\circledR} 7500$ instrument thermal cycler (Applied Biosystems) using 96-well optical barcode plates (Ref: 4306737) and Adhesive Optical Films Starter Kit (Ref: 4311971) following the manufacturer's instructions (Ingenetix, Austria). The real-time PCR amplification was carried out in a reaction mixture of $20 \mu \mathrm{L}$ composed of $5 \mu \mathrm{L}$ of sample (or genomic DNA) containing matrix DNA and 15 $\mu \mathrm{L}$ of Master Mix consisting of $3.0 \mu \mathrm{L}$ of water, $10 \mu \mathrm{L}$ of DNA mix reaction $(1 \mu \mathrm{L}$ of Listeria monocytogenes Mix Assay) for the detection of L. monocytogenes and $1 \mu \mathrm{L}$ of CR mix assay (Primers and Probes (Cy5) for IPC detection).

At least one negative control (water), one positive control (L. monocytogenes) and one negative extraction included by PCR were ensured.

According to Ingenetix recommendations, all PCR analyzes are done in duplicate to optimize the probability of detecting pathogens and facilitate the interpretations of results.

\section{Programming of the Temperature Profile}

The reaction was carried out in a DNA thermocycler (Applied Biosystems) at a preliminary denaturing temperature of the DNA in dry at $95^{\circ} \mathrm{C}$, followed by 45 cycles consisting of $5 \mathrm{~s}$ at $95^{\circ} \mathrm{C}$ for denaturation of DNA and $1 \mathrm{~min}$ at $60^{\circ} \mathrm{C}$ for polymerase-mediated primer extension.

\section{Results}

The results obtained were negative for all the samples analyzed, therefore the prevalence of L. monocytogenes in the 65 samples collected in this study is $0 \%$.

The results are analyzed in real time using 7500 software V2.0.6 and represented in the form of a curve (Fig.1).

The Fig. 1 shows a multiplication of the FAM signal only for the positive controls (diluted and undiluted) which means that the DNA of L. monocytogenes of the positive controls has been amplified. However, the samples show no multiplication of the FAM signal, signifying that no L. monocytogenes DNA was detected in the sample. The samples are interpreted as negative.

On the other hand, a multiplication of the Cy5 signal is observed for all the samples, which means that the positive signal of the internal positive control excludes the possibility of inhibition of the PCR. 


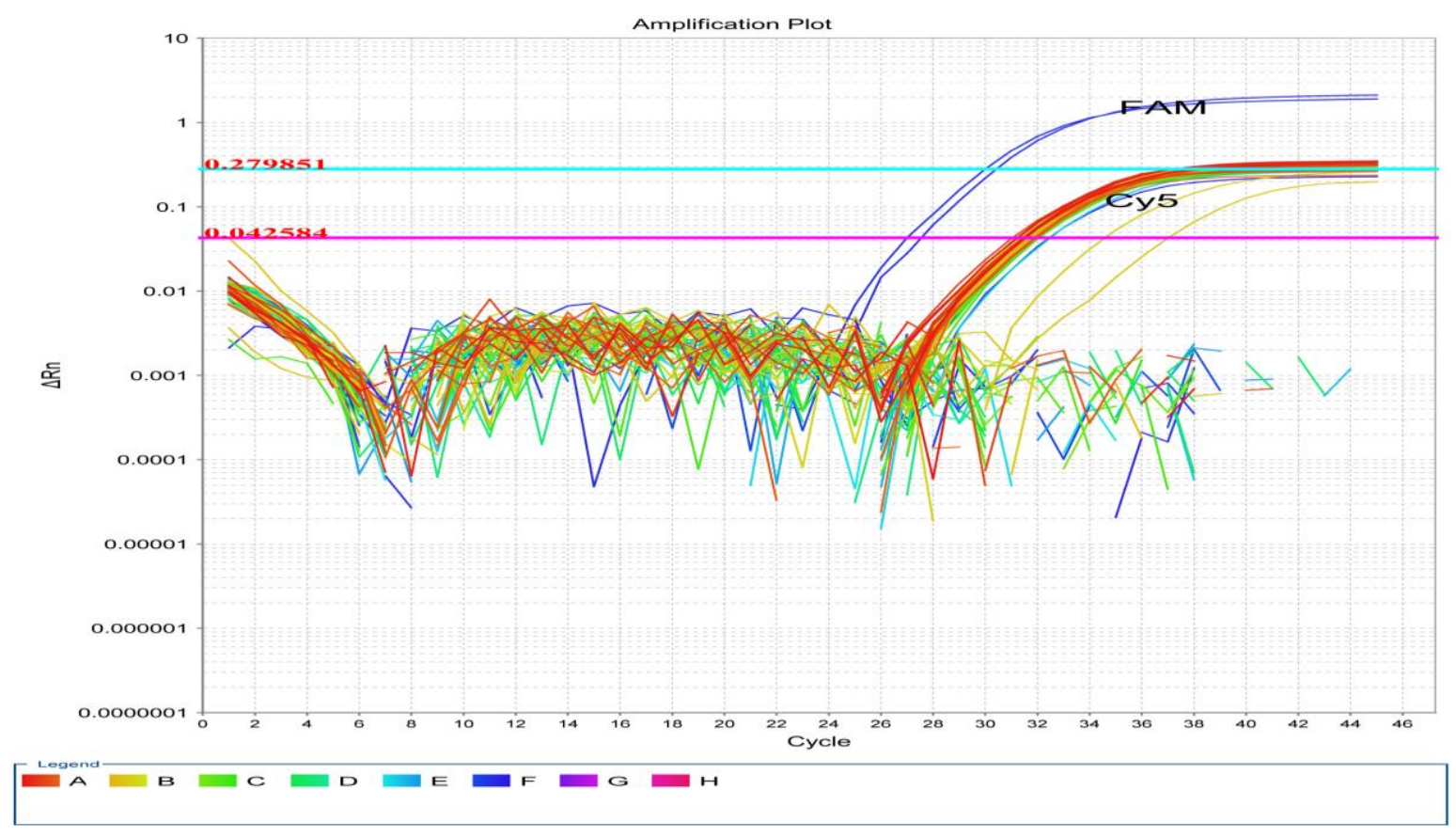

Fig. 1: Logarithmic curves for amplification of samples, positive and negative controls (FAM signal and Cy5)

\section{Discussion}

The absence of L. monocytogenes in our raw milk samples is in agreement with the results obtained by $\mathrm{Al}$ Kassaa et al. (2016). Studies in Italy and Switzerland have also shown negative results (Jemmi and Stephan, 2006).

Our results are lower than those of other studies carried out in other countries such as Turkey and Korea, where the prevalence was $4 \%$ for the first city (Vardar-Ünlü et al., 1998) and 2\% for the second (Ha et al., 2002). In Europe, the prevalence of listeriosis increased by $19.1 \%$ between 2008 and 2009 (EFSA, 2011). This increase had mainly occurred in people over 65 years of age $(58 \%)$ (Goulet et al., 2008). The prevalence of listeriosis is $6.5 \%$ in the United States (Van Kessel et al., 2004), 13\% in Brazil, 12\% in Canada (Jemmi and Stephan, 2006).

In the United States, investigations have indicated that L. monocytogenes is present in approximately $4 \%$ of the raw milk samples examined, as well as in unpasteurized milks and cheeses made from unpasteurized milk products (Washington et al., 2006).

The absence of L. monocytogenes in our raw milk samples and in those with similar results cited above may be due to unfavorable conditions for its colonization and its multiplication. Well-preserved silage may be one of the factors behind the absence of L. monocytogenes in cattle. Indeed, according to statistical analyzes by Vilar et al. (2007) the relationship between the poor quality of silage (due to the high $\mathrm{pH}$ ) and the presence of L. monocytogenes in silage is confirmed. They note isolation rates of $29.5 \%$ versus $6.2 \%$ for a $\mathrm{pH}$ above or below 4.5 , respectively.
These observations are also confirmed by numerous authors who have shown an increase in the carriage of Listeria spp. in winter and spring (October to June, depending on the country), times when animals, according to breeding techniques, are most often fed with silage. The portage of Listeria spp. exists in most herds (cows), with a rate varying between 0.5 to $10 \%$ of animals, depending on the season (AFSSA, 2000).

Jaradat et al. (2002) claimed in their work that the majority of animal contaminations by L. monocytogenes occurs in cold geographic regions such as North American and North European countries. This phenomenon can be explained by the increased risk of contamination during the housing of animals (Nightingale et al., 2005). The use of silage during the winter could also explain the increase in contamination cases during this period.

The absence of L. monocytogenes in our samples may be due to the sample collection period, taken during the summer in an aseptic manner thus avoiding the contamination of milk by environmental Listeria, to the presence of bacteriocins secreted by lactic acid bacteria belonging to the intestinal flora of cattle, or to the good health of selected dairy cows. Several research studies have confirmed the inhibitory effect of bacteriocins produced by Enterococcus strains against the growth and development of Listeria Spp. (Elotmani et al., 2002).

Human listeriosis is present in industrialized countries, but it appears to be almost absent from developing countries. In addition to the differences existing in the means of diagnosis and health surveillance, this geographical distribution could be explained by better 
hygiene and by the generalization of the cold chain in developed countries. Paradoxically, it seems that it is the good hygiene in the manufacturing processes and the development of the cold chain that are at the origin of an increase in the cases of listeriosis observed in the last forty years (FAO/WHO, 2002).

The increase in the incidence of human listeriosis in North American and North European countries could be explained by the aging of the population, the increase in the number of immunocompromised people (cancer patients, transplant patients, etc.), the evolution of eating habits favoring prepared meals, the significant consumption of risky foods (raw milk, cheeses, cold meats) and the increase in consumption deadlines (Desneux, 2015).

\section{Conclusion}

In conclusion, the prevention of listeriosis must be the subject of a community effort associating those responsible for veterinary medicine and public health. The systematic use of molecular techniques such as the realtime PCR technique would make it possible to detect all the animals that may be at the origin of human contamination and their elimination from consumption circuits.

\section{Acknowledgements}

The authors would like to thank the technical staff at the Laboratory of Microbiology and Molecular Biology of Constantine Biotechnology Research Center for their collaboration, in particular, Hamza Rahab, Abderrahmane Selmania and AssiaIkhlef. The authors declare that they did not have any funding source or grant to support this research work.

Funding Information: There is no financial/personal interest or belief.

\section{Authors' Contributions}

Sabrina Rabehi: Drafted and prepared the study design, carried out the research and analyzed the data.

Asma Meghezzi and Sabrina Rabehi: Executed the extraction of DNA.

Khaoula Boushaba and Sabrina Rabehi: Executed the real-time PCR.

Taha Mossadak Hamdi: Revised the manuscript

Bakir Mamache: Revised the manuscript and approved the final version.

\section{Ethics}

This article is original and contains unpublished material. The corresponding author confirms that all authors read and approved the final manuscript.

\section{References}

AFSSA (2000). (French Food Safety Agency) Report of the Commission for the study of risks linked toListeria monocytogenes, pp: 146. https://www.anses.fr/fr/system/files/MIC-RaListeria2000.pdf

Al Kassaa, I., El Omari, K., Esmail, B., Hamze, M., \& Saati, M. (2016). Prevalence of Listeria monocytogenes in raw milk in North Lebanon. Lebanese Science Journal, 37-43. doi.org/10.22453/LSJ-017.1.037043

Chentouf, H. F. (2015). Effect of antimicrobial substances produced by Leuconostocmesenteroidesisolated from Algerian camel milk on Listeria spp. in food products. Doctoral thesis, specialty: Applied microbiology. University of Oran, Algeria. https://theses.univ-oran1.dz/document/13201579t.pdf

Desneux, J. (2015). Study of the survival and viability of Listeria monocytogenes in the effluents of pig farms. Doctoral thesis. Option: Chemistry, University of Rennes-1. France.

Dmowska, K., Wieczorek, K., Lynch, O., \&Osek, J. (2013). Typing of Listeria monocytogenes isolated from slaughtered cattle and beef meat. Bull. Vet. Inst. Pulawy, 57, 179-183. doi.org/10.2478/bvip-2013-0033

EFSA. (2011). The community summary report on trends and sources of zoonoses, zoonotic agents and foodborne outbreaks in the European Union in 2009. (European Food Safety Authority). EFSA Journal, 9(3), 2090. doi.org/10.2903/j.efsa.2011.2090

Elotmani, F., Revol-Junelles, A. M., Assobhei, O., \& Milliere, J. B. (2002). Characterization of anti-Listeria monocytogenes bacteriocins from Enterococcus faecalis, Enterococcus faecium and Lactococcus lactis strains isolated from Raib, a Moroccan traditional fermented milk. Current microbiology, 44(1), 10-17. doi.org/10.1007/s00284-001-0067-8

FAO/WHO. (2002). World Forum of Food Safety Officers. Marrakech. Morocco, January 28 to 30, pp, 1-223. http://www.fao.org/3/y3680f/Y3680F03.htm\#Top OfPage

Gaillard, J. L., Berche, P. \& Sansonetti, P. (1986). Transposon mutagenesis as a tool to study the role of hemolysin in the virulence of Listeria monocytogenes. Infect. Immun., 52, 50-55. doi.org/10.1128/IAI.52.1.50-55.1986

Goulet, V., Hedberg, C., Le Monnier, A., \& De Valk, H. (2008). Increasing incidence of listeriosis in France and other European countries. Emerg. Infect. Dis., 14, 734-740. doi.org/10.3201/eid1405.071395

Ha, K. S., Park, S. J., Seo, S. J., Park, J. H., \& Chung, D. H. (2002). Incidence and polymerase chain reaction assay of Listeria monocytogenes from raw milk in Gyeongnam Province of Korea. J. Food Prot., 65, 111-115. doi.org/10.4315/0362-028X-65.1.111 
Hough, A. J., Harbison, S. A., Savill, M. G., Melton, L. D., \& Fletcher, G. (2002). Rapid enumeration of Listeria monocytogenes in artificially contaminated cabbage using real-time polymerase chain reaction. J. Food Prot., 65, 1329-1332. doi.org/10.4315/0362028X-65.8.1329

Hunt, K., Drummond, N., Murphy, M., Butler, F., Buckley, J., \& Jordan, K. (2012). A case of bovine raw milk contamination with Listeria monocytogenes. Irish Vet J, 65, 13.

Jaradat, Z. W., Schutze, G. E., \& Bhunia, A. K. (2002). Genetic homogeneity among Listeria monocytogenes strains from infected patients and meat products from two geographic locations determined by phenotyping, ribotyping and PCR analysis of virulence genes. Int. J. Food Microbiol., 76 (1-2), 1-10. doi.org/10.1016/s0168-1605(02)00050-8

Jemmi, T., \& Stephan, R. (2006). Listeria monocytogenes: food-borne pathogen and hygiene indicator. Rev. Sci. Tech. Off. Int. Epiz., 25, 571-580.

Kaismoune, N. (2009). Listeria monocytogenesand food products. Specialized post-graduation internship thesis. (INATAA) Universite Mentouri-Constantine, Algeria. https://bu.umc.edu.dz/theses/agronomie/KAI5413.pdf

Liu, D., Ainsworth, A. J., Austin, F. W., \& Lawrence, M. L. (2004). Use of PCR primers derived from a putative transcriptional regulator gene for speciesspecific determination of Listeria monocytogenes. Int. J. Food Microbiol., 91, 297-304. doi.org/10.1016/j.ijfoodmicro.2003.07.004

Magalhães, R., Ferreira, V., Biscottini, G., Brandão, T. R. S., Almeida G., \& Teixeira, P. (2017). Biofilm formation by persistent and non-persistent Listeria monocytogenes strains on abiotic surfaces. Acta Alimentaria, 46 (1), 43-50. doi.org/10.1556/066.2017.46.1.6

Millet, L., Saubusse, M., Didienne, R., Tessier, L., \&Montel, M. C. (2006). Control of Listeria monocytogenes in raw-milk cheeses. Int. J. Food Microbiol., 108, 105-114. doi.org/10.1016/j.ijfoodmicro.2005.11.004

Nightingale, K. K., Fortes, E. D., Ho, A. J., Schukken, Y. H., Grohn, Y. T., \&Wiedmann, M. (2005). Evaluation of farm management practices as risk factors for clinical listeriosis and fecal shedding of Listeria monocytogenes in ruminants. J. Am. Vet. Med. Assoc., 227, 1808-1814. doi.org/10.2460/javma.2005.227.1808
Shi, W., Qingping, W., Jumei, Z., Moutong, C., \& Zéan, Y. (2015). Prevalence, antibiotic resistance and genetic diversity of Listeria monocytogenes isolated from retail ready-to-eat foods in China. Food Control, 47, 340-347. doi.org/10.1016/j.foodcont.2014.07.028

Snapir, Y. M., Vaisbein, E., \& Nassar, F. (2006). Low virulence but potentially fatal outcome-Listeria ivanovii. Eur. J. Intern. Med., 17, 286-287. doi.org/10.1016/j.ejim.2005.12.006

Strawn, L. K., Gröhn, Y. T., Warchocki, S., Worobo, R. W., Bihn, E. A., \&Wiedmanna, M. (2013). Risk factors associated with Salmonella and Listeria monocytogenes contamination of produce fields. J. Appl. Environ. Microbiol., 79, 7618-7627.

doi.org/10.1128/AEM.02831-13

Van Kessel, J. S., Karns, J. S., Gorski, L., Mccluskey, B. J., \& Perdue, M. L. (2004). Prevalence of Salmonellae, Listeria monocytogenes and fecal coliforms in bulk tank milk on US dairies. J. dairy Sci., 87, 2822-2830. doi.org/10.3168/jds.S00220302(04)73410-4

Vardar-Ünlü, G., Ünlü, M., \& Bakici, M. Z. (1998). Incidence of Listeria spp. from Raw Milk in Sivas. Tr. J. Med. Sciences, 28, 389-392. https://dergipark.org.tr/tr/download/articlefile/129921

Vilar, M. J., Yus, E., Sanjuan, M. L., Dieguez, F. J., \& Rodriguez-Otero, J. L. (2007). Prevalence of and risk factors for Listeria species on dairy farms. J. dairy Sci., 90: 5083-5088. doi.org/10.3168/jds.2007-0213

Washington, W. J., Stephen, A., William, J., Koneman, E., Procop, G., \& Scheckenberger, P. (2006). Koneman's Color atlas and textbook of diagnostic microbiology. 6th ed. Philadelphia, United States: Lippincott Williams \& Wilkins, pp, 765-773. https://www.worldcat.org/title/konemans-coloratlas-and-textbook-of-diagnosticmicrobiology/oclc/58598402

Welchman, D. D., Hooton, J. K., \& Low, J. C. (1997). Ocular disease associated with silage feeding and Listeria monocytogenes in fallow deer. Vet Rec, 140, 684-685. https://www.cabi.org/isc/abstract/19972210768 